\title{
Decentralization Education System and Its Effects on Teachers Performance
}

\author{
Sadia Shabbir ${ }^{1}$, Ishtiaq Ahmed ${ }^{2}$, Muhammad Imran $^{3}$ \\ ${ }^{1}$ Department of English Literature, National College of Business Administration \& Economic Lahore (Multan Campus), Lahore, Pakistan \\ ${ }^{2}$ Department of Management Science, Virtual University of Lahore, Lahore, Pakistan \\ ${ }^{3}$ Department of Computer Science, University of Agriculture Faisalabad, Faisalabad, Pakistan
}

Email address:

Hayya.dnp@gmail.com (S. Shabbir), Ishtiak_ahmed@hotmail.com (I. Ahmed), Friendgcmscs@gmail.com (M. Imran)

\section{To cite this article:}

Sadia Shabbir, Ishtiaq Ahmed, Muhammad Imran. Decentralization Education System and Its Effects on Teachers Performance. Journal of Investment and Management. Vol. 6, No. 3, 2017, pp. 75-78. doi: 10.11648/j.jim.20170603.11

Received: July 1, 2017; Accepted: July 24, 2017; Published: October 18, 2017

\begin{abstract}
In this world, just those countries have survived and contended with challenges which have a quality and sound training framework. The nature of training relies upon use of labor and inspiration level of organization and educators. The education system throughout the world has been changed by the passage of time. Unfortunately, Pakistan government not gives proper attention to the education sector. After the creation of fifty-four years of Pakistan the decentralization education system introduced by the military government and some power has been devolved to at local level. This study conducted in district Lodhran (Punjab). The qualitative study method and convenient sampling technique was used to get the data. The present study main aim to know how decentralization education system affects the teacher and school performance and what role of the politician is negative or positive. Finally, in conclusion putting some suggestions that how to make the performance of teachers fruitful for education system and how local representatives play their positive role to provide the standard education to people.
\end{abstract}

Keywords: Decentralization, Education System, Education, Teacher Performance, Pakistan

\section{Introduction}

In this world, only those nations have survived and competed with challenges which have a quality and sound education system [1]. Education system throughout the world is public and private. The public school's management structure different from private schools. Both private and public schools aim to provide the quality education to people. The quality of education depends on utilization of manpower and motivation level of administration and teachers. If they work in a team and have a good communication between them they provide better education. In public schools seen that there is a gap of communication. This is the one main reason that jeopardizes the education system.

Pakistan is a developing country and has a need of vigilant and effective education management structure that not only fruitful of this nation but also meet with international standards. The education system of Pakistan is very weak. There are many reasons behind this such as politically instability, lack of knowledge of educational problems, the feudal system, and corrupt bureaucracy. The current education system of Pakistan not born the characterful person but born the persons that are a number of machines. The students think that good marks mean good knowledge. This system deprives the critical and innovative thinking from students.

The current literacy rate of Pakistan is 60 percent. The male and female literacy rates are 70 percent and 49 percent respectively. The province's situation is also worst, the Punjab, Sindh, Khyber Pakhtunkhwa and Balochistan provinces literacy rate are 63 percent, 60 percent, 53 percent and 44 percent respectively [2]. The factors such as cultural, lack of education facilities and poverty intervened in which literacy rate is low. In Pakistan education system divided into three segments first is government schools in which poor people of the society belong to this category. This system basic needs are classrooms, teachers, and textbooks. The majority of this school have not proper buildings and they opened under a tree. The second type of schools called the 
elite school. The elite class schools opened for the high elite class of the society. This class of schools education system and textbooks different from government poor society. The poor people cannot afford education in this type of school. The third type is madrasa where the education system is totally different from above mentioned. In this type of schools religious and school education provide to students.

Dropout rate is very high in government schools because of less intrest of teachers in trimming the students and least interference of education ministers. In south Punjab land lords wadeeraShahi, political system jeopardizes the education system. This situation worse for girls than boys [3]. [4] described that in Asia Pakistan one of them where government education system is worst and government aware of this bad system and not deal with this issue.

According to [5] absenteeism of teachers in government, schools are higher than in private schools. The student teacher ratio is high especially in rural areas in south Punjab. In lodhran, one teacher for girls and boys in primary schools is 35 and 68 respectively, in middle schools 38 and 63 respectively and in high schools for girls and boys are 70 and 43 respectively [6].

Today world quality, efficiency and equality are the core ingredients of education policy. Every country priorities are to increase education standard and raise the efficiency level of education system. For this purpose, they introducing different educational strategies. The decentralization education system is one of such strategies that increase the role of parental and community in school matters [7]. An educational management structure that is more connect with the local community and less resistance by the ministry of education work more efficient and effectively. Because of the local authority more aware of school needs [8]. School management may involve others to take the decision on an issue instead of taking the decision unilaterally. In education, the teachers, parents or community members are active actors that boost the school performance [9].

There are two types of decentralization: devolution and delegation. Devolution refers to the diffusion of authority and responsibility; this increased the more involvement of local authorities. The delegation implies diffusion of responsibility to the periphery of policies as decided centrally [10]. Decentralization education divides the school management system into smaller units, but the main power still remains in central management [11]. There are four factors that make decentralization education system successful or unsuccessful. The cultural context where decentralization education system exists. The second factor is political support from at national and local level. This factor highly affected on the system. The third factor is appropriate management planning to run the system. The fourth but utmost factor is empowerment. At local level empowerment became local representative more effective and more motivate [12].

[13] described that cultural issue, inconsistency, lack of administration handling problem and resistance from teachers causes the failure of decentralization system. According to [14] the decentralization is not a panacea. There is no guarantee that education will improve due to the decentralization because decentralized system differ from country to country and each country have its cultural, rules and policies. [15] described that decentralization only can be successful when it is necessary and central government transfer powers and resources to local government. In the world, most of the countries like Brazil, Nigeria, Egypt, Bangladesh even unitary country China adopted the decentralization education system and they devolved most of the powers at local levels. Indonesia adopts the decentralization education system and they have greater authority to schools to managing education programs [16].

The decentralization education introduced in Pakistan in 2001 by the military government. This was the great step in education. This system tries to make local participation in decision-making and devolution of power at grass root level. In education the aim of decentralization to increase the learning achievement and raised the efficiency [17]. According to [18] this is better and has a good indicator that decision should be made at the lowest level where competencies exist. If there is no criterion of power between federal, provincial and district level the whole system will be jammed [19]. The decentralized system shares the power to elected representative, the result of this that management efficiency enhances through accountability and establishes a good celebration between, federation, province and district level. The effective supervision is essential to provide the quality education. Unfortunately, in Pakistan, the process of supervision beautifully described in policies but not implemented in practically [20]. The diagram of decentralization education sysem shown under.

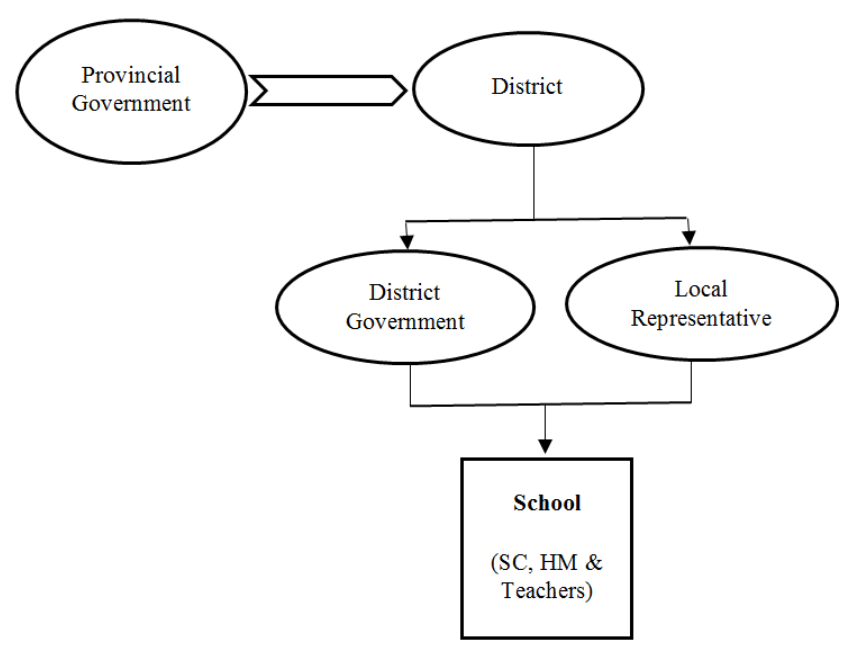

Figure 1. $S C=$ School Community, HM=Head Master.

There are 165000 primary schools in Pakistan where 19847000 students teach from 430000 teachers [2]. This research conducted in lodhran, so in lodhran there are 573 government primary schools and the number of male and female teachers are 775 and 897 . The numbers of middle schools in Lodhran are 151. The 695 male and 731 female teachers perform their duty in middle schools. There are 91 government high schools in Lodhran where 1008 male and 
543 female teachers teach to students [21].

In Pakistan, the researcher's attention on the decentralized system of public schools was less due to some restrictions. This study tries to know that decentralization system in public schools achieved its target goals and how this system positively and negatively affects the public school's and teachers performance.

\section{Objectives of the Study}

The main objectives of this study to know how decentralized education system enhances the teacher performance. This paper will try to know that what this educational structure achieved its goals. This study also identifies the role of local representative.

(1) To know decentralization educational School performance.

(2) To know the role of local representative in decentralization education system.

(3) To know the school monitoring process in decentralization education system.

(4) To know the teacher performance in decentralization education system.

\section{Methodology/Research Design}

The qualitative research method was used in this study. The district lodhran was a target for this purpose where litracy rate is very low. Out of 91 government high schools of Lodhran city [21] the 21 government high schools were visited. The 87 teachers and head masters interviews were conducted. The individual and group based interview, both methods were used in this research. The interview were close and open ended and the research team consists of two members. The four questions were asked to respondents and taken their viewpoints on it. The first question was "the effect of decentralization on teachers" the second question was "the effect of decentralization on public school performance" the third question was "the decentralization and effective monitoring" and fourth question about "the role of a politician in decentralization education".

Table 1. Employees Job

\begin{tabular}{ll}
\hline Employees Job & \\
\hline Head Masters & 21 \\
Teachers & 66 \\
Total & 87 \\
\hline
\end{tabular}

Table 2. Respondents Demographic.

\begin{tabular}{ll}
\hline Respondent Demographic & \\
\hline Male & 69 \\
Female & 18 \\
Total & 87 \\
\hline
\end{tabular}

Table 3. Respondents Education.

\begin{tabular}{ll}
\hline Education & \\
\hline M. Phil / MS & 6 \\
Master & 71 \\
Bachlor & 10 \\
Total & 87 \\
\hline
\end{tabular}

Table 4. Respondents Length of Service.

\begin{tabular}{ll}
\hline Service & \\
\hline Below 1 to 5 Years & 18 \\
Between 6 to 9 Years & 24 \\
Between 10 to 15 Years & 31 \\
Between 16 to 22 Years & 14 \\
Total & 87 \\
\hline
\end{tabular}

\section{Result and Discussion}

\subsection{Effective Monitoring}

The $72 \%$ respondents recommend that this system increases the monitoring process due to community involvement. The community members keep an eye on school matters and this fear bond the teachers that they follow the school rules and time table. After, the implementation of decentralization the teacher's attendance increased compared to the past. The respondents also reflected that unfair political interfere in monitoring government schools create a stress among school teachers.

\subsection{Role of Politician}

The $83 \%$ respondents told that role of the politician in government schools matters are negative. The political representative protects their own interest. Wihout any reason the politician transfer the teacher's from one school to other school this fear badly affect the teachers performance and teachers live in stress. Political interfere destroy the school system and teacher's face much pressure from politician side. Politician also interferes in departmental inquiry matters and try to affect on the decision.

\subsection{Public School Performance}

There is a close relationship between school administration and community in the success of decentralization system. The decentralization increases the community involvement in decision-making and they perform as an active participent. The $68 \%$ respondents informed that decentralization increases the government schools performance because community members directly involved in schools matter and they give their suggestions on the issue that school faces. If the teacher face an issue he put his problem in front of community members or local representative without any hesitation.

\subsection{Teacher Performance}

The $77 \%$ respondents informed that the role of community members should be advisory and their decision and voice not a decisive because the head teacher and staff teachers are responsible for the good or bad result of students. The community members not responsible for bad results. If the result of students bad or poor the head and other staff declared responsible for punishment. So the respondents declared that if interfere of local representative limited, this system is better for teachers and the teachers performance will boost. 


\section{Conclusion}

The Lodhran city is not a well established district here litracity rate is below then average as compare to other city of the south Punjab. The local representatives also not well educated and their interest in education development is not active in past. The commnication of local representative and school administrative not well established and priodically.

The main aim of decentralization to a mobilization of community in school matters. The success of this system is depends on community and school administration relations. The role of school administration is utmost in this scenario because the community cannot function without the help and cooperation of school administration. This is the assumption of the school head that he shares all the information with community members. Sometimes seen that there is create a conflict between school head and community members because the school head does not show the accounts and other matters. This imperative behavior inclined to community members to impede in school matters.

Strong communication between all stakeholders (e.g, political representative, community members, school head) and availability of resources is necessary to sustain and improvement of education in localities. The local representative has needed a visionary leadership quality and school head has a motivational ability to convince others. The local representative must avoid making school matters political, the result of students will be better. At the end, the overall result of this study revealed that local representative misuse of his power and stimulate the politics among teachers. If the political representative not involved in school matters the decentralization education helpful for education and this system will also increase the teachers and school performance and it leads to make success in the world.

\section{References}

[1] Cohen, D. K., \& Ball, D. L. (1990). Relations between policy and practice: A commentary. Educational Evaluation and Policy Analysis, 12, 331-338.

[2] Ministry of Finance. (2015). Economic Survey of Pakistan. Islamabad: Ministry of Finance, Government of Pakistan.

[3] Farah, I. and K. Bacchus. (1999). Educating girls in Pakistan: Tensions between economics and culture. In Education, culture and economics: Dilemmas for development, ed. L. Fiona and L. Angela, 225-37. New York: Garland.

[4] Reimers, F., \& Warwick, D. P. (1995). Hope or despair? Learning in Pakistan's primary schools. London: Praeger.

[5] Andrabi, T. J., Das, A. I., Khawja, T., Vishwanath and Zajonc. (2008). Learning and Educational Achievement in Punjab Schools LEAPS Lahore: 197.

[6] Warraich, N. A. 2008. Causes of Low Enrolment and Possible Local Options to Address Them. Multan: Canada Pakistan Basic Education Project (CPBEP) 18.
[7] Chen, D. (2011). School-Based Management, School Decision-Making and Education Outcomes in Indonesian Primary Schools, The World Bank East Asia and Pacific Region Education Sector Unit.

[8] Androniceanu, A. (2011). Transparency of the Romanian Local Public Administration. Administration and Public Management Review, 17, 33.

[9] Lunenburg, F. C., \& Ornstein, A. C. (2008). Educational Administration: Concepts and Practice. Belmont, CA: Wadswoth/Cengage.

[10] Aasen, P. (2004). What happened to social-democratic progressivism in Scandinavia? Restructuring education in Sweden and Norway in the 1990s. In: M. W. Apple (Ed.), The state and the politics of knowledge London: Taylor \& Francis e-Library, pp. 1-24.

[11] Lunenburg, F. C., \& Ornstein, A. C. (1996). Educational Administration: Concepts and Practice. Wadsworth Publishing Company. USA.

[12] Richardson, Michael, D., Gentry., Linda, R., Kenneth, E., Vanberkum, Dennis, W. (1994). Science La Liability for Teacher: Protect yourself when Administrators Don't. J. Chem. Educ, 71 (8).

[13] Vientian, Lao (2002). Designing and Implementing Local Curricula. Final report of Building the Capacities of Curriculum specialists for Educational Reform. UNESCO, International Bureau of Education. Bangkok.

[14] Amin Khanadaghi, M., \& Dehghani, M. (2010). Reflecting on Centralization, Decentralization and Returning to Centralization. Journal of Educational and Psychological Studies. Ferdowsi University of Mashhad.

[15] Gershberg, I A. (1998). Decentralisation, Recentralisation and Performance Accountability: Building an Operationally Useful Framework for Analysis, Development Policy Review, 16 (4), 405-431.

[16] Winkler, D. R., \& Cohen, J. (2005). The s tatus of decentralization: A three-day workshop for national and subnational stakeholders. Washington, D. C: USAID. Retrieved March 13, 2009, from http://www.equip123.net/ docs/e2DecentralizationWorkshop.pdf

[17] Bray, M. (1994). Centralization/Decentralization and Privatization/Publicization: Conceptual issue and the need for more research, International Journal of Educational Research, $21(8), 817-824$.

[18] Fisher, R. J. (2000). Decentralization and Centralization in Forest Management: A Conceptual Overview. In: Enters.

[19] Geo-JaJa, M. A. (2006). Educational decentralization, public spending, and social justice in Nigeria. International Review of Education, 52 (1-2), 129-153.

[20] Goll, I., \& Rasheed. A. A. (2004). The Moderating Effect of Environmental Munificence and Dynamism on the Relationship between Discretionary Social Responsibility and Firm Performance. Journal of Business Ethics, 49 (1).

[21] GOP (2017). Government pof the Punjab, Retrieved April, 14, 2017, www.punjab.gov.pk 